\title{
Bedden voor daklozen \\ blijken snel geregeld in \\ coronatijd
}

\section{De coronacrisis maakt pijnlijk duidelijk hoe snel een financieel probleem kan ontstaan, met als uiterste consequentie dakloosheid. Overal in het land poppen creatieve oplossingen op om mensen onderdak te bieden. Maar dat zijn geen permanente woningen, terwijl huisvesting een recht is voor iedereen. Herstel begint immers met een huis.}

DOOR Tea Keijl

$\mathrm{H}$ erstel begint met een huis, zo luidt ook de titel van het adviesrapport ${ }^{1}$ van de Raad voor de Volksgezondheid en Samenleving (RVS) dat afgelopen april verscheen. 'Je moet ergens een begin hebben waar je rust creëert en van waaruit je de volgende stappen kunt zetten', zei RVS-voorzitter Jet Bussemaker bij de presentatie. In het rapport wordt niet nadrukkelijk de link met corona gelegd, maar de huidige crisis laat wel zien hoe trefzeker de lijnen in het rapport zijn geschetst. Een belangrijke constatering van de RVS is dat de groep meer divers is geworden; de raad onderscheidt vier categorieën mensen zonder onderdak: na vertrek uit een justitiële of ggz-instelling, na huisuitzetting, bij remigratie en na een ingrijpende gebeurtenis zoals een relatiebreuk of baanverlies. De algemene overtuiging is dat deze laatste categorie de komende tijd hard zal groeien, ondanks alle overheidsmaatregelen om zoveel mogelijk banen te behouden.

\section{Veldbedjes}

Ook al vóór de coronapandemie groeide het aantal daklozen hard: de afgelopen tien jaar verdubbelde het aantal tot bijna 40.000. Het Leger des Heils sloeg direct alarm in de eerste weken dat het virus rondwaarde met de campagne 'Thuisblijven, hoe dan?!' Behalve dat thuisblijven per definitie onmogelijk is voor dakloze mensen, was het voor hen in de coronatijd extra lastig om überhaupt ergens binnen te zijn door de gesloten bibliotheken en buurthuizen. In de inloophuizen gold of geldt vaak een maximale verblijfsduur. De maatschappelijke (nacht-)opvang kampt met overbezetting. Bovendien verblijven deze mensen met een vaak zwakke gezondheid daar noodgedwongen met meerdere personen in één ruimte, zegt Cornel Vader, directeur Welzijns- en Gezondheidszorg op de website. ${ }^{2}$ Maar, zegt hij ook: 'Veldbedjes in een lege sporthal - steeds op minstens anderhalve meter afstand - lossen het tekort aan woonruimte niet op.' Dit soort noodoplossingen vanwege de anderhalve meter afstand zijn door het hele land te vinden. Zoals een voormalige gevangenis in Maastricht, een hotel in Dordrecht en leegstaand zorgvastgoed in Roosendaal. De crisis maakt duidelijk dat er met daadkracht en creativiteit snel noodverbanden aangelegd kunnen worden. Maar het zijn tijdelijke oplossingen. En dat is precies het grootste bezwaar van Nienke Boesveldt, hoofdonderzoeker dakloosheid aan de Universiteit van Amsterdam. 'Daklozen kunnen over het algemeen nog minder goed tegen veranderingen dan de meeste andere mensen. Ik hoop dat deze crisis helpt om door te laten dringen dat ze niet zomaar een dak boven hun hoofd moeten hebben, maar een permanent huis.'

\section{Woonhotel}

Toch ziet Boesveldt wel degelijk positieve kanten aan de huidige creatieve oplossingen. 'Hostels en hotels bijvoorbeeld, die kunnen structureel een deel van hun kamers openstellen. Dat kan bijvoorbeeld een uitkomst zijn voor de vierde categorie, de economische daklozen. Publiek-private samenwerkingen op dat vlak zijn interessant. Een mooi privaat initiatief is een sociaal ondernemer die een gedeelte van de opbrengst van de reguliere gasten van zijn woonhotel inzet voor kamers voor daklozen.'

Verder is het goed denkbaar dat het Rijksvastgoedbedrijf helpt door locaties zoals voormalige gevangenissen structureel in te zetten. Er zijn nu tijdelijke samenwerkingsovereenkomsten tussen anti-kraakvastgoedbeheerders en gemeenten. Dat zou wellicht een 


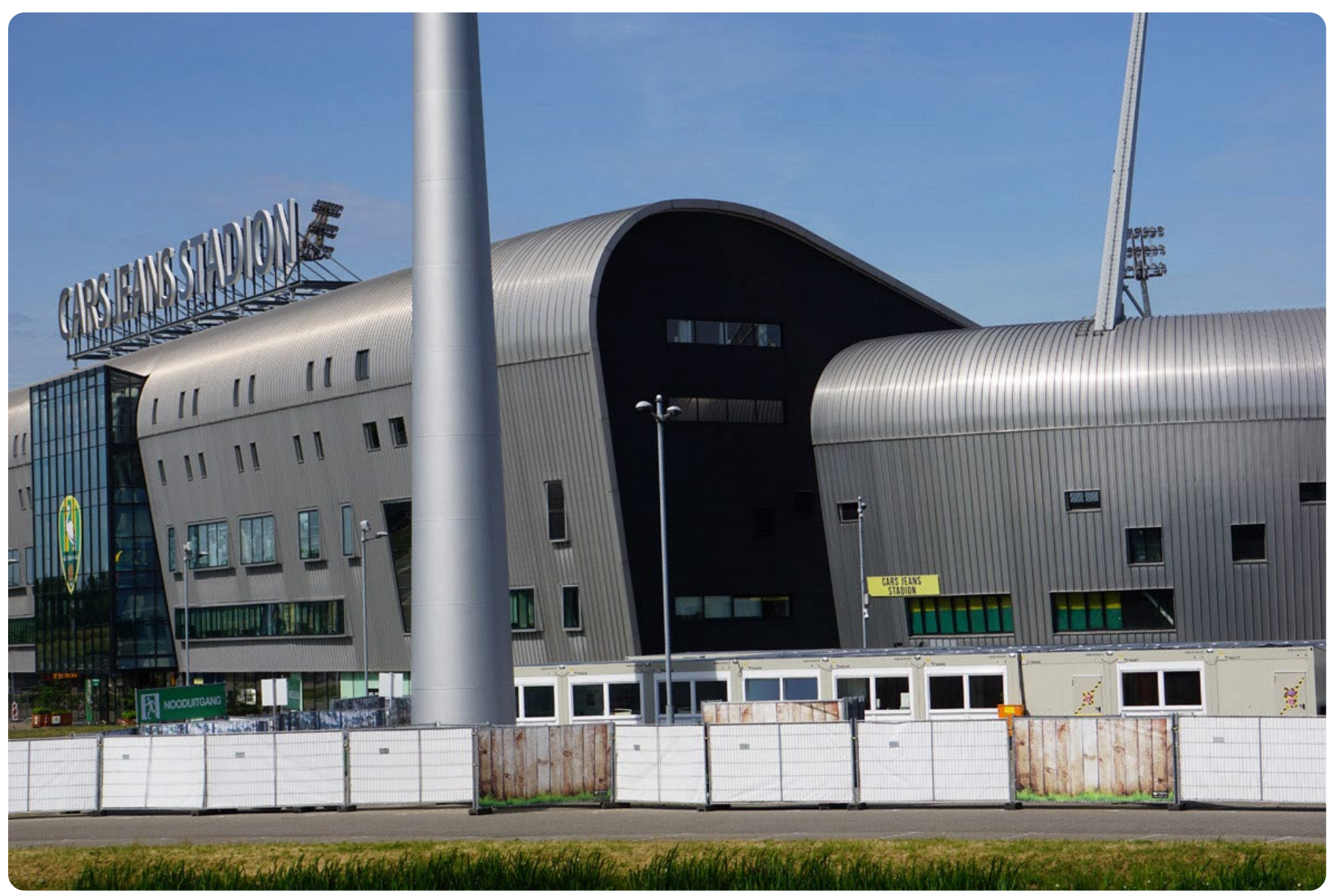

Razendsnel opgezette noodopvang voor met COVID-19 besmette daklozen bij het Cars Jeans Stadion in Den Haag. Twee maanden na de afkondiging van de lockdown was er nog geen keet bewoond.

structureel karakter kunnen krijgen. Gemeenten kunnen ook overwegen om permanente bewoning op vakantieparken toe te staan. Ze hebben daar mogelijkheden voor. VNG en Platform31 zeggen hierover in hun rapport: ${ }^{3,4}$

'Legaliseren is een optie als bewoning veelvuldig en langdurig voorkomt en een vakantiepark zich daar ook goed voor leent.'

\section{Een recht}

Net als Boesveldt ziet ook Esmé Wiegman, directeur van Valente, de branchevereniging van de maatschappelijke opvang, dit soort initiatieven slechts als een deel van de oplossing. 'De coronacrisis maakt eens te meer duidelijk', zegt Wiegman, 'dat het noodlot iedereen kan treffen. Het is bizar hoe hard het kan gaan, hoe diep je kunt wegzakken en hoe lang het duurt voor je hulp krijgt.' Beide deskundigen waren er altijd al van overtuigd dat preventie een veel belangrijker weg is. De RVS benadert preventie, dus het voorkómen van dakloosheid, vanuit het recht op huisvesting. Jet Bussemaker: 'Je wordt dakloos doordat je je woning verliest. Zo simpel is het. Dus als huisvesting een recht is, gebeurt dit minder vaak en zal het aantal daklozen niet toenemen maar afnemen.

Volgens Wiegman is deze benadering een belangrijke stap in de goede richting. 'Daklozenopvang heeft nog vaak de bijklank van liefdadigheid. Maar een dak boven je hoofd is dus geen gunst, het is een recht.'

De benadering van huisvesting als een recht past binnen een andere beweging die de directeur van Valente de laatste tijd signaleert: de beweging naar meer vertrouwen in de burger. Een positievere benadering komt daarmee in de plaats van het signaleren en bestraffen van fraude, dat jarenlang de boventoon voerde in beleid en uitvoering. 'Staatssecretaris Paul Blokhuis benoemt steeds opnieuw dat het groeiende aantal daklozen niet moet kunnen in een rijk land als Nederland. Zijn ambities, zoals het verlagen van de verhuurdersheffing en in totaal twee miljard euro voor extra woningen, kunnen richting geven aan het handelen van professionals zoals bij gemeentelijke diensten W\&I en bij woningverhuurders.

Ook zijn recente oproep om 'artikel vijf' wat vaker te hanteren, ${ }^{5}$ kan voor hen een duwtje in de rug zijn. Boesveldt trekt het nog wat breder: 'Alles en iedereen moet vragen naar de woonsituatie', zegt ze. 'Ook de leerkracht, de huisarts, het wijkteamlid. Toon interesse: hoe woon je, lukt het om de huur op tijd te betalen? Dat moet een sociale professional gewoon kunnen, die skills heeft hij. Dat hoort bij zijn opdracht om zo integraal mogelijk uit te vragen op alle leefgebieden.'

\section{Business}

Om huisuitzettingen te voorkomen, zouden woningcorporaties en het sociaal domein elkaar beter moeten kennen, vindt Boesveldt. Woningcorporaties ervaren te vaak dat ze een 'roepende in de woestijn zijn', weet ze. 'Ze vinden elkaar niet binnen de keten. En dan ontstaan er onwenselijke constructies. Zoals dat de zorgaanbieder of de gemeente het huurcontract op zich neemt, met de bijbehorende risico's op 
de kosten van een ontruiming in geval van ernstige overlast. Dat kost zo'n vifftienduizend euro per keer. Maar je moet je afvragen: wat hoort bij wie? Het woningbeheer en het huurdersbestand zijn de business van de corporatie; zorgen dat een huurder kan blijven huren is de business van de zorgaanbieder. Het gaat nu nog te vaak over het afdekken van risico's.'

De woningcorporatie zou standaard aan tafel moeten zitten bij het overleg van het wijkteam, meent ze. 'Dat kan ervoor zorgen dat net op tijd het goede gesprek gevoerd wordt. Heeft een huurder de badkamer gesloopt? Wat heeft die persoon dan nodig aan dagbesteding, wie kan welke ondersteuning bieden?' Ook bepleit Boesveldt kortere lijntjes tussen de woningcorporatie en de gemeentelijke schuldhulpverlening. 'Het zou goed zijn als de schuldhulpverlener laat weten aan de corporatie dat er gewerkt wordt aan de situatie huurachterstand en dat de betalingen in orde komen. Ook die wetenschap kan huisuitzettingen voorkomen.' Dit gebeurt in de praktijk al wel en is ook wat beoogd wordt met het voorgestelde wijziging van de Wet gemeentelijke schuldhulpverlening, die gegevensuitwisseling regelt met het oog op vroegsignalering.

\section{Kostendelersnorm}

Een ander financieel aspect waar gemeenten een rol in kunnen spelen, betreft de kostendelersnorm. Al in 2015 signaleerde Sociaal Bestek dat die funest kan uitpakken. ${ }^{6}$ Hoe zat het ook al weer? Het korten op de bijstandsuitkering naar rato van het aantal bewoners van een huis, vergroot de kans op dakloosheid. En wel langs twee routes. Ouders die van de bijstand moeten rondkomen en een kind boven de 21 jaar in huis hebben, worden zoveel gekort dat zij soms niet meer kunnen rondkomen.

Sommigen vragen dan hun kind het huis uit te gaan, zeker als er toch al spanningen zijn. De tweede manier waarop de kostendelersnorm nadelig kan uitpakken, is als de jongere vervolgens bij vrienden met een bijstandsuitkering aanklopt. In dat geval moet degene die hem onderdak biedt, opgeven dat hij de woning deelt en krijgt híj met de kostendelersnorm te maken.
'Over de kostendelersnorm is al ontzettend veel gedacht en gesproken', zegt Boesveldt. Die discussie gaat in feite over de interpretatie van de Participatiewet. Meer specifiek over de vraag welke mogelijkheden gemeenten hebben om soepel om te gaan met de kostendelersnorm. Het gaat dan over artikel 18, lid 1: 'Het college stemt de bijstand en de daaraan verbonden verplichtingen af op de omstandigheden, mogelijkheden en middelen van de belanghebbende. ${ }^{7}$ Volgens de betrokken bewindslieden hebben gemeenten hiermee voldoende mogelijkheden, zo lieten ze eind vorig jaar weten in een Kamerbrief: ${ }^{8}$ Het kabinet is van mening dat de huidige wet- en regelgeving veel ruimte geeft voor het bieden van maatwerk waardoor iedereen op een goede manier geholpen kan worden. Er is geen aanleiding om in wet- en regelgeving een categoriale uitzondering te introduceren voor daken thuislozen.'

\section{Opgetuigd}

De RVS adviseert het rijk in het eerder genoemde rapport desondanks expliciet om de regels te versoepelen. De raad stelt voor 'dat het rijk het mogelijk maakt om de uitvoering van de kostendelersnorm te bevriezen voor bepaalde doelgroepen (bijvoorbeeld kwetsbare jongeren tot 27 jaar) zolang er te weinig woningaanbod voor hen is'. Ook Boesveldt toont zich voorstander van een meer directieve opdracht vanuit de landelijke overheid. 'Nu kunnen 380 gemeenten zelf bedenken hoe ze ermee omgaan. Sommige klantmanagers zeggen nu gewoon: "Dat doen we niet bij ons", als de vraag komt om de individuele omstandigheden te betrekken bij de norm.' Wat haar betreft zou bovendien niet de hoofdhuurder gekort moeten worden op de uitkering, maar de extra bewoner.

Of er nu wel of niet een aanpassing in de wet komt, er zijn sowieso al bewegingen ten gunste van de dakloze personen waar te nemen. Zo gaan de ministeries van SZW en VWS de komende tijd samen met de VNG en Divosa aan de slag om de maatwerkmogelijkheden die de Participatiewet biedt nader bij de uitvoering onder de aandacht te brengen. ${ }^{9}$ En hierboven is al de richtinggevende houding van Blokhuis genoemd. Dat kan een individuele klantmanager sturen en steunen in zijn oordeel, denkt Wiegman van Valente: 'We hebben nu de staatssecretaris achter ons. Elke functionaris moet zich realiseren: de overheid is er om zich in te zetten voor de meest kwetsbaren. Om daar de dingen voor te regelen, om hen te beschermen. Dáár hebben we de overheid voor opgetuigd.'

\section{Toch uitgezet}

Hoewel zowel Wiegman als Boesveldt vooral het belang van preventie benadrukt, zien ze allebei ook de realiteit van een groeiende groep dakloze mensen. Voor Wiegman is het essentieel dat de hulpverlening hen ziet als gewone mensen. 'De vragen die dakloze mensen hebben, zijn dezelfde vragen als die van andere kwetsbare mensen. Hoe kom ik mijn dag goed door? Hoe kom ik aan eten? Hoe deal ik met mijn verslaving?' Boesveldt sluit zich van harte aan bij deze constatering, en ziet er bovendien een falen van het systeem in. 'Dakloosheid moet niet als iets aparts gezien worden. Maar dat is in het huidige systeem wel aan de hand. Als iemand dakloos raakt, dan belandt hij ineens in een heel ander hulpverleningscircuit. Dan zijn ze ineens van de opvang. De professionals in de opvang hebben hun takenpakket in de loop der jaren enorm zien verbreden. Naast de daadwerkelijke opvang doen ze bijvoorbeeld ook aan schuldhulpverlening en verslavingszorg. Terwijl daar elders in het sociaal domein specialisten voor zijn.'

In het verlengde van deze constatering gebruikt de onderzoeker tegenwoordig de term 'extreme woonbehoefte', in plaats van 'dakloos'. 'Bij de term dakloze bestaat nog te sterk het beeld van iemand met een vieze baard en een verwarde blik. Maar die vieze baard hoort bij de kapper, voor de verwarde blik is de hulpverlening aan zet. De maatschappelijke opvang lenigt de nood van de extreme woonbehoefte. Daarom vind ik die term beter passen.'

\section{Begeleiding}

Er is een gat tussen wat er is aan hulpverlening en de dakloze persoon, ziet de onderzoeker. Het opvullen van dat gat is niet alleen de taak van de casemanager, die iedereen die zich bij de maatschappelijke opvang meldt krijgt toegewezen. 'Het vindt en bereikt elkaar 
niet. Dát moet verbeteren. Het bestaande aanbod moet zich het lot van de daklozen aantrekken, hen ook tot de doelgroep rekenen.' Het zou niet uit moeten maken of iemand wel of niet een dak heeft, betoogt ze verder. 'Uit diverse onderzoeken blijkt dat de kans op terugval aanzienlijk en heftig is. Wel veertig tot vifftig procent van de mensen in de nachtopvang hebben die niet voor het eerst van hun leven nodig. En wat blijkt: van al deze mensen die zijn teruggevallen, had niemand begeleiding op het moment van terugval.' En dat is lang niet altijd omdat het bij voorbaat al zorgmijders waren, weet ze. 'Het zijn zorgvuldige zorgzoekers. Daarmee bedoel ik dat zij de zorg die zij nodig hebben, moeilijk kunnen vinden. Ik sprak met een ex-militair met PTSS, die kon helemaal niks met de begeleider die hij toegewezen had gekregen: veel te jong, nauwelijks levenservaring. Terwijl er een lotgenotencontactgroep is bij het militair revalidatiecentrum in Doorn.' Zo'n zoektocht maken veel daklozen door, en lang niet altijd met een positieve afloop. De inzet van ervaringsdeskundigen kan eraan bijdragen dat meer daklozen de hulpverlening als positief ervaren, denkt Boesveldt. 'Ook intensieve begeleiding zoals FACT-teams die geven, kan een uitkomst zijn. Maar die teams zijn niet altijd bereikbaar voor deze mensen, omdat een woning hebben een vereiste is.'

\section{Housing First}

Daarom nog één keer terug naar de titel van het RVS-rapport: Herstel begint met een huis. Boesveldt maakte eerder al duidelijk dat het idealiter om een permanent huis gaat. Ze wijst op het bewijs voor Housing First. 'Gewoon een structureel huis, liefst met een eigen huurcontract en vanaf dag nul passende begeleiding.' Alleen dan los je het probleem echt op, zeggen ook andere pleitbezorgers van deze aanpak. De meer traditionele aanpak werkt volgens hen met een zogenaamd woonladdermodel, waardoor de dakloosheid vooral wordt gemanaged. ${ }^{10}$

In diverse landen, waaronder als bekend voorbeeld Finland, ${ }^{11}$ maar ook in Amerika, zijn er voldoende bewijzen voor de effectiviteit van de aanpak. Sinds het eerste Amsterdamse initiatief in 2006 zijn er nu verspreid over het land ruim dertig praktijken, met gemiddeld tussen de vijfentwintig en vijftig deelnemers. In totaal gaat het naar schatting om twaalf- tot veertienhonderd mensen, en dat op het totaal van 40.000. Waarom komt het in Nederland nog maar mondjesmaat van de grond? Is dit uitsluitend te wijten aan het slot op de onderkant van de woningmarkt? 'Nee, er speelt veel meer', zegt Boesveldt. Net als bij de kwestie van de kostendelersnorm wijst ze ook hier op het gebrek aan nationale regie. Mede daardoor ziet ze een verwatering van het concept. 'Elke centrumgemeente kan er iets op laten ontwikkelen. Het wordt niet altijd op de bedoelde manier geïmplementeerd. Het is bedoeld voor de allerlastigste gevallen. Maar wat er nu gebeurt is dat juist de lichtere groepen het krijgen. Bovendien is er te weinig goede kennisoverdracht; er is geen hogeschool die het onderwijst.'

\section{Nationale regie}

Dakloosheid is al met al een hardnekkig en terugkerend vraagstuk. De vraag wie verantwoordelijk is voor wat laat zich niet makkelijk beantwoorden. Het is een complex en gelaagd geheel: woningcorporaties, zorgaanbieders, individuele gemeenten, 43 centrumgemeenten en de landelijke overheid. Met simpelweg meer woningen en aanbevelingen als 'goede samenwerking is nodig' kom je er dus niet, dat beseft zowel Boesveldt als Wiegman. Meer nationale regie lijkt geboden. Boesveldt stelde in 2015 in haar proefschrift al dat 'beleid op dakloosheid weliswaar het beste werkt wanneer het lokaal op maat wordt gemaakt, maar dat sommige beslissingen wel centraal genomen dienen te worden'. Ook Wiegman denkt dat althans een deel van de oplossing zit in meer centrale aansturing. Valente schreef hierover al eerder in Sociaal Bestek en bepleitte toen onder meer wetswijzigingen voor wat betreft de vier weken wachttijd voor jongeren die een uitkering aanvragen en de verhuurderheffing voor woningcorporaties. ${ }^{12}$ Wiegman noemt daarnaast het op landelijk niveau instellen van quota per gemeente als optie. 'Bij de opgave om statushouders een woning te bieden werken quota ook. Je moet bij de doelgroep van daklozen natuurlijk wel heel goed kijken naar de grote diversiteit. Een puur economische dakloze met een gezin kun je natuurlijk niet naar de andere kant van het land verplaatsen. Maar voor iemand zonder netwerk, of een netwerk in het criminele circuit, kan dat juist wel heel helpend zijn.'

Tea Keijl is freelance journalist in het sociaal domein.

Bij het ter perse gaan van dit artikel stuurden de bewindslieden Blokbuis, Ollongren en Van Ark in een Kamerbrief bun plan van aanpak naar de Tweede Kamer. De aanpak beoogt 10.000 extra woonplekken te realiseren, voor 1 januari 2022. Zie Kamerbrief en artikel Zorg+Welzijn.

\section{Noten}

1 www.raadrvs.nl/documenten/publicaties/ 2020/04/21/herstel-begint-met-een-huis--dakloosheid-voorkomen-en-verminderen

2 https://www.legerdesheils.nl/thuisblijven

3 https://www.platform31.nl/publicaties/ meer-grip-op-vakantieparken

4 Zie ook https://www.zorgwelzijn.nl/ magazine-artikelen/integrale-aanpakvoor-permanente-bewoners-met-socialepsychische-of-financiele-problemen/

5 https://www.socialevraagstukken.nl/ interview/paul-blokhuis-over-40-000daklozen-minder-opvang-meer-woningen/ ?utm_source=mailpoet\&utm_medium= email\&utm_campaign=paul-blokhuis-over40-000-daklozen-liever-huizen-bouwen-danopvangen-in-voorzieningen_47

6 Zie pagina 4 van de Memorie van Toelichting: https://www.rijksoverheid.nl/documenten/ kamerstukken/2019/10/14/tk-pdv-139069-bijl-2mvt-wijz-wgs-tbv-de-uitwisseling-van-persoonsgegevens-nader-rapport. Het voorstel is aangenomen in de Tweede Kamer en wordt op het moment van schrijven van dit artikel behandeld in de Eerste Kamer.

7 Bommeljé (2015). 'Explosieve toename vermijdbare daklozen: De voorzienbare gevolgen van de kostendelersnorm', in Sociaal Bestek 77 (6), 6-8

8 Zie bijvoorbeeld: www.schulinck.nl/opinie/ opinie-sociaal-domein-participatiewet-deindividualiseringsbepaling-in-de

9 www.rijksoverheid.nl/documenten/ kamerstukken/2019/12/06/kamerbriefover-terugdringen-van-dakloosheid

10 Zie bijvoorbeeld www.divosa.nl/nieuws/ gemeenten-rijk-en-maatschappelijke-organisaties-bundelen-krachten-tegen-dakloosheid

11 www.socialevraagstukken.nl/housing-firstdakloosheid-stoppen-in-plaats-van-managen/

12 Hurk, van den en Boesveldt (2018). 'Aanpak dakloosheid: Finland heeft de weg gevonden', in Sociaal Bestek 80 (5), 36-38

13 https://www.zorgwelzijn.nl/magazine-artikelen/ van-nachtopvang-wordt-niemand-beter/ 